\title{
DETERMINAN PENINGKATAN PENDAPATAN MUSTAHIK PENERIMA MANFAAT ZAKAT PRODUKTIF PADA BAZNAS KABUPATEN SEMARANG
}

\author{
Nur Khalim Darwiyati dan Asrori \\ Universitas Negeri Semarang, Indonesia \\ Email: nurkhalim636@gmail.com dan asrorife@gmail.com
}

\begin{abstract}
This study aims to examine the effect of the level of education, type of productive business, length of effort, the amount of productive zakat, and assistance on increasing the income of productive zakat beneficiaries mustahik. The population in this study were 80 recipients of productive zakat beneficiaries at BAZNAS Semarang Regency in 2018, amounting to 80 people. The sampling technique was carried out by purposive sampling method which resulted in 40 research samples. The data used are primary data taken using a questionnaire. Data analysis techniques to test hypotheses using logistic regression analysis. The results showed that the type of business and the amount of productive zakat partially had a significant positive effect on the increase in mustahik income. Meanwhile, the level of education, length of business, and partially mentoring did not have a significant effect on increasing mustahik income. The conclusion of this research is the income of mustahik at BAZNAS Semarang Regency has increased if supported by sufficient capital. In addition, mustahik who carry out the production process experience an increase in income, the valueadded process to the resulting product increases consumer interest and affects income.
\end{abstract}

Keywords: education level; type of business; length of business; amount of productive zakat; assistance; increased income
Abstrak
Penelitian ini bertujuan untuk menguji pengaruh tingkat pendidikan, jenis usaha produktif, lama usaha, jumlah zakat produktif, dan pendampingan terhadap peningkatan pendapatan mustahik penerima manfaat zakat produktif. Populasi dalam penelitian ini adalah mustahik penerima manfaat zakat produktif pada BAZNAS Kabupaten Semarang tahun 2018 berjumlah 80 orang. Teknik pengambilan sampel dilakukan dengan metode purposive sampling yang menghasilkan 40 sampel penelitian. Data yang digunakan merupakan data primer yang diambil menggunakan kuesioner. Teknik analisis data untuk menguji hipotesis menggunakan analisis regresi logistik. Hasil penelitian menunjukkan jenis usaha dan jumlah zakat produktif secara parsial berpengaruh positif signifikan terhadap peningkatan pendapatan mustahik. Sementara itu, tingkat pendidikan, lama usaha, dan pendampingan secara parsial tidak berpengaruh signifikan terhadap peningkatan pendapatan mustahik. Simpulan dari penelitian ini yaitu pendapatan mustahik pada BAZNAS Kabupaten Semarang mengalami peningkatan jika didorong oleh

$\begin{array}{ll}\text { How to cite: } & \text { Darwiyati, Nur Khalim dan Asrori (2021) Determinan Peningkatan Pendapatan Mustahik Penerima } \\ & \text { Manfaat Zakat Produktif pada Baznas Kabupaten Semarang. Syntax Literate: Jurnal Ilmiah Indonesia } \\ & \text { 6(4). http://dx.doi.org/10.36418/syntax-literate.v6i4.2267 } \\ \text { E-ISSN: } & \text { 2548-1398 } \\ \text { Published by: } & \text { Ridwan Institute }\end{array}$


permodalan yang cukup. Selain itu, mustahil yang melakukan proses produksi mengalami peningkatan pendapatan, adanya proses value added terhadap produk yang dihasilkan meningkatkan minat konsumen dan berpengaruh terhadap perolehan pendapatan

Kata Kunci: tingkat pendidikan; usaha produktif; lama usaha; jumlah zakat produktif; pendampingan; peningkatan pendapatan

\section{Pendahuluan}

Kemiskinan merupakan permasalahan yang sangat krusial bagi bangsa Indonesia dan belum teratasi sampai saat ini. Kemiskinan merupakan suatu kondisi dimana masyarakat tidak mampu memenuhi kebutuhan dasarnya. Disebut miskin apabila pendapatan yang diperoleh tidak mampu memenuhi kebutuhan dasar. Data dari BPS (2020) menunjukkan bahwa pada September 2019, 9.22\% penduduk Indonesia berada dibawah garis kemiskinan nasional. Kemiskinan terus terkonsentrasi pada daerah pedesaan, $12.60 \%$ penduduk desa dan $6.56 \%$ penduduk kota berada dibawah garis kemiskinan. Meskipun jumlah orang miskin terus berkurang, namun secara keseluruhan ketimpangan berdasarkan ukuran indeks gini mengalami peningkatan dan puncaknya pada tahun 2020 mencapai 0.381 (BPS, 2020). Hal ini menunjukkan ketimpangan pendapatan yang semakin melebar.

Berbagai upaya telah dilakukan untuk mengatasi kemiskinan salah satunya dengan pemanfaatan zakat untuk memberdayakan pelaku usaha kecil. Unit usaha kecil memiliki peran yang cukup penting bagi perekonomian nasional. Dibalik kontribusinya yang cukup baik bagi perekonomian nasional, unit usaha kecil memiliki berbagai macam permasalahan. Permasalahan unit usaha kecil diantaranya kurangnya jiwa kewirausahaan, kompetensi sumber daya manusia yang rendah, akses ke lembaga keuangan yang terbatas, dan tidak memiliki jaringan usaha (Suryanto \& Muhyi, 2018). Permasalahan tersebut menyebabkan usaha kurang berkembang dan pendapatan mustahik tidak meningkat secara signifikan.

Zakat menjadi instrumen yang tepat untuk mengatasi permasalahan kemiskinan. Zakat merupakan kewajiban setiap muslim untuk memberikan sebagian hartanya kepada pihak yang lemah. Hasil sensus penduduk Indonesia pada tahun 2010 menunjukkan bahwa jumlah penduduk muslim di Indonesia mencapai $87.18 \%$ (BPS, 2010) dan potensi zakat di Indonesia pada tahun 2019 mencapai 233.84 triliun (Puskas BAZNAS, 2019). Potensi yang sangat besar tersebut jika dikelola dengan optimal akan menjadikan zakat sebagai instrumen yang tepat untuk mengatasi permasalahan kemiskinan. Zakat berperan sebagai pendukung peningkatan ekonomi apabila disalurkan dalam bentuk zakat produktif (Sartika, 2008). Penyaluran zakat produktif akan digunakan oleh mustahik sebagai modal usaha, pemberdayaan ekonomi mustahik dan memenuhi kebutuhan jangka panjang.

Penyaluran zakat produktif, bantuan diberikan sesuai dengan permasalahan yang dihadapi. Mustahik yang memiliki kendala permodalan akan diberikan bantuan baik berupa uang maupun barang untuk dijadikan modal. Sedangkan mustahik dengan 
kendala kompetensi sumber daya manusia rendah akan diberikan pelatihan dan pendampingan yang dikelola langsung oleh lembaga zakat. Harapannya dengan adanya permodalan yang cukup dan didukung oleh pengetahuan dan kemampuan yang memadai, mustahik dapat mengembangkan usahanya sehingga pendapatan usaha meningkat.

Beberapa penelitian yang meneliti tentang faktor-faktor yang mempengaruhi pendapatan mustahik dan keberhasilan mustahik dalam mengembangkan usaha telah banyak dilakukan dan menjadi sumber rujukan dalam penelitian ini. Ayuniyyah, et al (2018) dalam penelitiannya membuktikan bahwa pendidikan formal secara statistik berpengaruh signifikan terhadap peningkatan jumlah pendapatan. Hasil penelitian serupa juga dilakukan oleh Syafiq \& Suprayogi (2020) bahwa tingkat pendidikan memiliki pengaruh positif terhadap pendapatan mustahik. Vu (2020) menyatakan "that education, measured by any indicators, has a positive effect on household income". Namun hasil penelitian berbeda dilakukan oleh beberapa penelitian antara lain dalam penelitian Amir (2019), Muhammad, et al (2018), Nabela (2017) mengungkapkan bahwa pendidikan tidak berpengaruh terhadap pendapatan dan keberhasilan usaha.

Perbedaan hasil penelitian terjadi pada variabel jenis usaha. Qomariah (2019) menyatakan bahwa jenis usaha memiliki pengaruh positif terhadap peningkatan pendapatan mustahik. Hasil penelitian berbeda dilakukan oleh Muhammad, et al (2018) bahwa jenis usaha tidak berpengaruh terhadap keberhasilan mustahik dalam menjalankan usaha. Mendukung hasil penelitian tersebut Amir (2019) bahwa jenis usaha tidak berpengaruh terhadap pendapatan mustahik.

Perbedaan penelitian juga terjadi pada variabel lama usaha yang mana masih menunjukkan hasil penelitian yang beragam. Taufiq, et al (2018) menyatakan "business experience represents the length of time a mustahiq has run their business". Taufiq, et al (2018) membuktikan dalam penelitiannya bahwa pengalaman bisnis yang dilihat dari lama seseorang dalam menjalankan usaha memiliki pengaruh positif terhadap pendapatan. Hal tersebut didukung oleh hasil penelitian Muhammad, et al (2018), Amir (2019), Syafiq \& Suprayogi (2020) bahwa lama usaha berpengaruh terhadap pendapatan mustahik. Hasil penelitian tersebut memiliki perbedaan hasil dengan penelitian Nabela (2017) dan Dwipayanti \& Kartika (2020) yang menunjukkan bahwa lama usaha tidak berpengaruh terhadap pendapatan.

Jumlah zakat produktif yang diberikan untuk digunakan sebagai modal usaha menunjukkan hasil penelitian yang beragam. Khan (2014) "The contribution of microfinance to household welfare shows an increase in income”. Taufiq, et al (2018) dalam penelitiannya menunjukkan bahwa zakat produktif berpengaruh positif signifikan terhadap pendapatan. Hasil penelitian serupa dilakukan oleh Nabela (2017), Amir (2019), Prawira D \& Dewi (2019), Syafiq \& Suprayogi (2020), bahwa modal memiliki pengaruh positif terhadap pendapatan. Hasil penelitian berbeda dilakukan oleh Majid \& Suparno (2018) bahwa modal tidak berpengaruh terhadap pendapatan. Variabel pendampingan dalam beberapa penelitian menunjukkan hasil yang inconsistane. Penelitian Amir (2019) dan Syafiq \& Suprayogi (2020) menunjukkan 
bahwa pendampingan berpengaruh terhadap pendapatan. Sementara itu, hasil penelitian berbeda dilakukan oleh Firdausi (2019) bahwa pendampingan tidak berpengaruh terhadap pendapatan dhuafa.

Adanya fenomena gap dan banyaknya perbedaan hasil penelitian sebelumnya (research gap) yang dapat dikatakan bahwa hasil penelitian dalam topik ini masih inconsistance menjadi faktor pendorong diadakannya penelitian kembali dengan variabel yang digunakan adalah tingkat pendidikan, jenis usaha produktif, lama usaha, jumlah zakat produktif, dan pendampingan terhadap variabel dependen yakni peningkatan pendapatan mustahik. Dengan demikian, tujuan dari penelitian ini untuk mengkaji pengaruh tingkat pendidikan, jenis usaha produktif, lama usaha, jumlah zakat produktif, dan pendampingan terhadap peningkatan pendapatan mustahik.

Penelitian tentang pengaruh pendayagunaan zakat produktif terhadap peningkatan pendapatan mustahik ini merujuk pada penelitian yang telah dilakukan oleh Nabela (2017), Amir, (2019), dan Syafiq \& Suprayogi (2020) mengenai faktor-faktor yang mempengaruhi tingkat pendapatan. Penelitian diatas mengambil modal, jenis usaha, lama usaha, tingkat pendidikan, dan pendampingan sebagai variabel dependen dan menghasilkan hasil penelitian yang belum konsisten. Selain itu dari beberapa penelitian tersebut juga mengambil variabel tingkat pendapatan sebagai variabel terikat.

Kebaruan yang terdapat dalam penelitian ini dibandingkan dengan beberapa penelitian tersebut yaitu pada penelitian ini peneliti menghadirkan kembali variabel yang telah ada pada penelitian sebelumnya akan tetapi dengan pengukuran yang berbeda. Variabel jenis usaha produktif dalam penelitian ini diukur dengan menggunakan variabel dummy. Skor 1 untuk mustahik yang menjalankan usaha produksi dan skor 0 untuk mustahik yang tidak menjalankan usaha produksi. Variabel pendampingan pada penelitian ini diukur dengan menggunakan keikutsertaan mustahik dalam kegiatan pendampingan. Sedangkan variabel terikat dalam penelitian ini pengukurannya menggunakan selisih pendapatan rata-rata per bulan yang diperoleh oleh mustahik sebelum dan sesudah menerima bantuan zakat produktif. Penelitian ini dilakukan pada mustahik penerima manfaat zakat produktif pada BAZNAS Kabupaten Semarang.

Penelitian ini didasarkan pada teori kualitas sumber daya manusia dan teori pemberdayaan. Teori kualitas sumber daya manusia menurut Rahardjo (2010) bahwa indikator kualitas sumber daya manusia dilihat dari kualitas intelektual dan pendidikan. Individu yang memiliki pengetahuan dan keterampilan yang bagus serta pendidikan yang sesuai dengan bidangnya dapat memberikan sumbangan berharga untuk pencapaian tujuan. Anwas (2013) menyebutkan bahwa pemberdayaan adalah proses untuk memberikan daya atau kekuasaan kepada pihak yang lemah untuk mengurangi kekuasaan pihak yang berkuasa sehingga terjadi keseimbangan. Pemberian daya atau kekuasaan itu bisa berupa sumber daya, kesempatan, pengetahuan, maupun keahlian sehingga masyarakat dapat meningkatkan kualitas hidupnya.

Berdasarkan teori kualitas sumber daya manusia, tingkat pendidikan menjadi salah satu aspek yang digunakan untuk mengukur kualitas sumber daya manusia. 
Pendidikan merupakan kegiatan seseorang untuk mengembangkan pengetahuan, kemampuan, dan sikap untuk persiapan kehidupan saat ini dan masa depan. Semakin tinggi jenjang pendidikan yang ditempuh maka peluang untuk mendapatkan kehidupan yang lebih layak semakin tinggi karena pengetahuan dan kemampuan semakin berkembang. Modal manusia yang dilihat dari tingkat pengetahuan, keterampilan, dan pengalaman meningkatkan keunggulan organisasi (Alomari et al, 2020). Berdasarkan uraian tersebut, peneliti menyimpulkan bahwa keberhasilan dalam menjalankan usaha salah satunya dipengaruhi oleh jenjang pendidikan yang ditempuh oleh pelaku usaha. Semakin tinggi jenjang pendidikan yang ditempuh maka tingkat pengetahuan, keterampilan, dan kemampuan yang dimiliki akan semakin meningkat sehingga menghasilkan kinerja yang baik dan berdampak pada keberhasilan dalam mengembangkan usaha dan meningkatkan pendapatannya.

Menurut $\mathrm{Vu}$ (2020) bahwa pendidikan diukur dengan pengukuran apapun akan menghasilkan pengaruh yang positif terhadap pendapatan. Hal senada juga diungkapkan oleh Ayuniyyah, et al (2018) dan Syafiq \& Suprayogi (2020) bahwa tingkat pendidikan yang ditempuh berpengaruh terhadap pendapatan. Hal ini disebabkan karena mereka yang memiliki pendidikan lebih tinggi memiliki respon yang rasional dibandingkan mereka yang berpendidikan rendah.

\section{$\mathrm{H}_{1}$ : Tingkat pendidikan berpengaruh positif terhadap peningkatan pendapatan mustahik}

Jenis usaha merupakan jenis kegiatan yang dijalankan oleh pelaku usaha baik berupa dagang, manufaktur maupun jasa. Jenis usaha yang dijalankan sangat dipengaruhi oleh kemampuan pelaku usaha dalam melihat potensi pasar dan sumber daya yang ada disekitarnya. Dalam penelitian ini jenis usaha dibedakan menjadi dua yaitu jenis usaha produktif dan non produktif. Usaha produktif merupakan cara atau upaya yang dilakukan dengan mengerahkan seluruh sumber daya yang ada untuk menghasilkan sesuatu sehingga mendapatkan keuntungan yang lebih tinggi.

Usaha produktif merupakan usaha yang dilakukan dengan mengerahkan segala upaya untuk menghasilkan sesuatu yang lebih tinggi sehingga dapat mendatangkan keuntungan yang lebih besar. Pengaruh usaha produktif terhadap peningkatan pendapatan di latarbelakangi oleh teori produksi. Teori produksi pada dasarnya menjelaskan bagaimana dengan biaya minimum unit usaha dapat menghasilkan output tertentu atau memaksimumkan produksi. Menurut Sadono Sukirno produksi merupakan kegiatan yang dilakukan untuk menghasilkan barang atau jasa yang dapat dimanfaatkan oleh manusia. Proses produksi dilakukan dengan menambah nilai guna suatu barang atau jasa (Ahyari, 2002). Kegiatan menambah nilai tersebut bermanfaat untuk meningkatkan kualitas produk yang dihasilkan sehingga diharapkan dapat menarik minat konsumen dan meningkatkan harga jual suatu produk. Selain itu, dengan dilakukan proses produksi maka pelaku usaha dapat meminimumkan biaya produksi yang digunakan.

Jenis usaha produktif yang didalamnya terdapat proses produksi untuk memberikan nilai tambah pada produk yang dihasilkan memiliki pengaruh positif 
terhadap peningkatan pendapatan pelaku usaha. Selain itu, dengan melakukan proses produksi pelaku usaha dapat menimumkan biaya produksi sehingga akan berdampak pada perolehan keuntungan. Oleh karena dalam proses produksi terdapat proses value added terhadap produk yang dihasilkan dan dapat dilakukan penekanan biaya produksi maka akan berpengaruh terhadap pendapatan.

\section{H2: Jenis usaha produktif berpengaruh positif terhadap peningkatan pendapatan mustahik.}

Justifikasi pengaruh lama usaha terhadap peningkatan pendapatan mustahik diberikan oleh teori kualitas sumber daya manusia yang menyatakan bahwa sumber daya manusia yang berkualitas memiliki peluang lebih besar untuk mencapai tujuan. Menurut Soegoto (2014) kualitas sumber daya manusia bukan hanya dilihat dari kekuatan fisiknya melainkan dilihat dari pendidikan, pengalaman, dan kematangan sikap dan nilai yang dimiliki. Taufiq, et al (2018) mengatakan "business experience represents the length of time a mustahiq has run their business".

Lama usaha memberikan gambaran seberapa besar pengalaman seseorang dalam menjalankan usaha. Lama waktu adalah masa kerja yang telah ditempuh oleh seseorang sehingga ia bisa memahami dan mendalami tugas-tugas suatu pekerjaan dan dapat melaksanakannya dengan baik. Indikator seseorang dianggap berpengalaman menurut Foster \& Seeker (2001) salah satunya adalah lama masa kerja. Semakin lama seseorang bekerja secara tidak langsung akan mendapatkan jaringan usaha yang lebih luas dan bermanfaat bagi perolehan laba. Dalam hal ini mustahik yang telah lama menjalankan usaha dianggap memiliki pengetahuan dan kemampuan mumpuni yang diperoleh dari pengalamannya. Pengetahuan dan kemampuan tersebut akan mempengaruhi kemampuan mustahik dalam menjalanakan usaha dan menghasilkan pendapatan.

\section{H3: Lama usaha berpengaruh positif terhadap peningkatan pendapatan mustahik}

Pengaruh jumlah zakat terhadap peningkatan pendapatan mustahik dilandasi oleh teori pemberdayaan. Priono dan Pranarkan menyampaikan bahwa pemberdayaan merupakan proses sosial dan personal individu untuk mendorong kekuatan, kompetensi, kreativitas, dan kebebasan individu. Pemberdayaan yang dimaksud yaitu memberikan daya atau kekuasaan kepada pihak yang lemah dan mengurangi kekuasaan dari pihak yang terlalu berkuasa sehingga terjadi keseimbangan (Djohani, 2003). Hakikat pemberdayaan bagaimana membuat masyarakat mampu membangun diri dan memperbaiki kehidupannya.

Pemberdayaan mustahik penerima manfaat zakat produktif dilakukan dengan memberikan bantuan berupa uang atau barang untuk digunakan sebagai modal usaha serta pendampingan. Modal yang diberikan merupakan cara lembaga zakat memberi kuasa atau daya kepada mustahik agar dapat mengembangkan usaha. Pelaku usaha yang memiliki kendala permodalan diberikan bantuan zakat produktif berupa modal usaha sehingga mustahik dapat mengembangkan usahanya.

Modal merupakan faktor yang mempengaruhi pendapatan. Bantuan zakat produktif yang diterima oleh mustahik diterima dalam bentuk uang dan barang untuk 
digunakan sebagai modal usaha. Semakin besar bantuan zakat produktif yang diterima maka keuntungan yang dihasilkan juga semakin besar (Muda \& Arfan, 2016) sehingga pendapatan usaha pun akan semakin meningkat. Zakat produktif yang diberikan sebagai modal usaha menjadi salah satu upaya dalam memberdayakan ekonomi mustahik. Beberapa hasil penelitian Nabela (2017), Amir (2019), dan Syafiq \& Suprayogi (2020) menunjukkan bahwa modal memiliki pengaruh positif signifikan terhadap pendapatan. Hal ini menunjukkan bahwa jumlah bantuan zakat produktif yang diterima mustahik untuk digunakan sebagai modal memiliki pengaruh positif terhadap peningkatan pendapatan mustahik.

\section{H4: Jumlah zakat produktif berpengaruh positif peningkatan pendapatan mustahik}

Teori pemberdayaan memaknai pemberdayaan sebagai proses sosial yang dilakukan untuk meningkatkan kemampuan masyarakat agar lebih mandiri. Akhyadi \& Sadikin (2020) menyebutkan "Community empowerment is an effort to provide power or strength for the community to be independent and get away from problems they have been through". Pemberdayaan dilakukan dengan berbagai cara salah satunya melalui pendampingan. Sistem pendampingan dan pembelajaran langsung dinilai cukup lebih efektif dalam proses pemberdayaan apalagi jika tujuan pemberdayaan tersebut untuk mensejahterakan masyarakat (Akhyadi \& Sadikin, 2020).

Pendampingan merupakan usaha yang dilakukan oleh lembaga zakat sebagai pendamping terhadap pelaku usaha. Pendampingan dilakukan baik dari segi usaha maupun moral. Menurut Departemen Sosial RI pendampingan merupakan proses pembimbingan terhadap masyarakat miskin yang dilakukan oleh fasilitator melalui serangkaian aktivitas sehingga suatu komunitas memiliki kemampuan dan kepercayaan diri dalam menghadapi permasalahan di seputar kehidupannya. Pendampingan dilakukan agar bantuan modal dan potensi sumber daya yang ada dapat digunakan dengan maksimal dan sesuai sasaran. Pendampingan juga dilakukan dengan memberikan motivasi dan konsultasi atas permasalahan yang dihadapi oleh mustahik. Dengan adanya pendampingan dapat mendorong kegiatan usaha lebih terarah dan sesuai sasaran sehingga usaha dapat berkembang dan pendapatan mustahik meningkat. Oleh karena itu, diasumsikan bahwa dengan pendampingan dapat meningkatkan pendapatan mustahik. Hal ini terjadi karena secara tidak langsung pendampingan melalui motivasi dan dorongan yang diberikan dapat memperbesar peluang mustahik dalam meningkatkan pendapatan.

\section{H6: Pendampingan berpengaruh positif terhadap peningkatan pendapatan mustahik.}

Berdasarkan kerangka berpikir di atas, model penelitian yang digunakan dalam penelitian ini ditunjukkan dalam gambar 1 : 


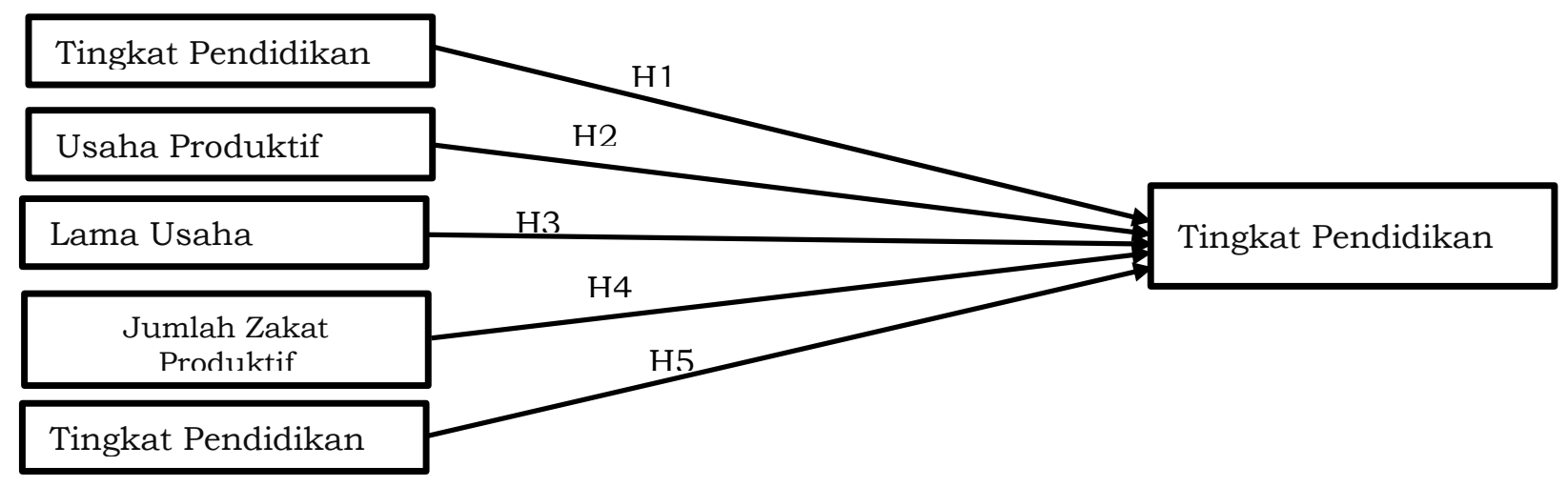

Gambar 1

Model Penelitian

\section{Metode Penelitian}

Penelitian ini merupakan penelitian kuantitatif dengan menggunakan data primer. Teknik pengambilan sampel dalam penelitian ini menggunakan teknik purposive sampling dengan kriteria yang ditetapkan, sehingga menghasilkan 40 sampel penelitian. Tabel 1 menunjukkan kriteria yang digunakan dalam pengambilan sampel pada penelitian ini.

\section{Tabel 1}

Proses Pengambilan Sampel Penelitian

\begin{tabular}{clc}
\hline No & \multicolumn{1}{c}{ Kriteria } & Jumlah \\
\hline 1 & Mustahik merupakan penerima manfaat zakat produktif pada BAZNAS & 80 \\
& Kabupaten Semarang. & $(40)$ \\
2 & Usaha yang dijalankan masih berjalan sampai tahun 2020 & 40 \\
Jumlah & 40 \\
Jumlah perusahaan yang dijadikan sampel & 0 \\
Data outliers & Total unit analisis & 40 \\
\hline
\end{tabular}

Sumber: Data Sekunder diolah, 2020

Penelitian ini menggunakan enam variabel penelitian yang terdiri atas satu variabel dependen yaitu peningkatan pendapatan, lima variabel independen: tingkat pendidikan, jenis usaha produktif, lama usaha, jumlah zakat produktif, dan pendampingan. Definisi operasional variabel penelitian disajikan pada tabel 2.

Tabel 2

Definisi Operasional Variabel Penelitian

\begin{tabular}{llll}
\hline Nama Variabel & \multicolumn{1}{c}{ Definisi } & \multicolumn{1}{c}{ Indikator } & Pengukuran \\
\hline Peningkatan & Perubahan & Pendapatan setelah & Dummy \\
Pendapatan (Y) & pendapatan yang & mengikuti program & Variable \\
& dihasilkan usaha & pemberdayaan dikurangi & \\
& mikro sebelum dan & pendapatan sebelum & \\
& sesudah & mengikuti program & \\
& mendapatkan & pemberdayaan (Firdausi, & \\
\hline
\end{tabular}




\begin{tabular}{|c|c|c|c|}
\hline & $\begin{array}{l}\text { bantuan dana zakat } \\
\text { produktif } \\
\text { (Qomariah, 2019) }\end{array}$ & 2019) & \\
\hline $\begin{array}{l}\text { Tingkat } \\
\text { pendidikan }\left(\mathrm{X}_{1}\right)\end{array}$ & $\begin{array}{lr}\text { Pendidikan } & \text { formal } \\
\text { terakhir } & \text { yang } \\
\text { ditempuh } & \text { oleh } \\
\text { mustahik. } & \\
\text { (UU No } 20 & \text { tahun } \\
\text { 2003) } & \end{array}$ & $\begin{array}{l}\text { Mengelompokkan } \\
\text { pendidikan formal menjadi } \\
4 \text { yaitu: } \\
\text { a. SD } \\
\text { b. SMP } \\
\text { c. SMA } \\
\text { d. PT } \\
\text { (Muhammad et al., 2018) }\end{array}$ & Interval \\
\hline $\begin{array}{l}\text { Jenis Usaha } \\
\text { Produktif }\left(\mathrm{X}_{2}\right)\end{array}$ & $\begin{array}{lr}\text { Klasifikasi usaha } \\
\text { yang dijalankan oleh } \\
\text { seseorang guna } \\
\text { memperoleh } \\
\text { pendapatan (Amir, } \\
\text { 2019) }\end{array}$ & $\begin{array}{l}\text { Jenis usaha dikelompokkan } \\
\text { menggunakan variabel } \\
\text { dummy } \\
\text { (Amir, 2019) }\end{array}$ & $\begin{array}{l}\text { Dummy } \\
\text { Variable }\end{array}$ \\
\hline $\begin{array}{ll}\text { Lama } & \text { Usaha } \\
\left(\mathrm{X}_{3}\right) & \end{array}$ & $\begin{array}{lr}\text { Waktu usaha } & \text { atau } \\
\text { pengalaman } & \text { dalam } \\
\text { menjalankan } & \\
\text { aktifitas } & \text { usaha. } \\
\text { (Syafiq } & \& \\
\text { Suprayogi, 2020) } & \end{array}$ & $\begin{array}{l}\text { Jangka waktu yang sudah } \\
\text { ditempuh oleh mustahik } \\
\text { dalam menjalankan usaha } \\
\text { (Syafiq \& Suprayogi, 2020) }\end{array}$ & $\begin{array}{l}\text { Rasio } \\
\text { (Tahun) }\end{array}$ \\
\hline $\begin{array}{l}\text { Jumlah zakat } \\
\text { produktif }\left(\mathrm{X}_{4}\right)\end{array}$ & $\begin{array}{l}\text { Besaran dana zakat } \\
\text { yang diberikan oleh } \\
\text { BAZNAS kepada } \\
\text { mustahik (Amir, } \\
2019 \text { ) }\end{array}$ & $\begin{array}{l}\text { jumlah semua penerimaan } \\
\text { bantuan zakat produktif } \\
\text { (Amir, 2019) }\end{array}$ & $\begin{array}{l}\text { Rasio } \\
\text { (Rupiah) }\end{array}$ \\
\hline $\begin{array}{l}\text { Pendampingan } \\
\left(\mathrm{X}_{5}\right)\end{array}$ & $\begin{array}{l}\text { Kegiatan yang } \\
\text { dilakukan agar usaha } \\
\text { tetap berjalan dan } \\
\text { berkembang, seperti } \\
\text { pelatihan, } \\
\text { bimbingan, } \\
\text { pemberian arahan, } \\
\text { pengawasan. (Amir, } \\
\text { 2019) }\end{array}$ & $\begin{array}{lr}\begin{array}{l}\text { Keikutsertaan } \\
\text { dalam }\end{array} & \begin{array}{r}\text { mustahik } \\
\text { kegiatan }\end{array} \\
\text { pendampingan } & \\
\text { (Syafiq \& Suprayogi, 2020) }\end{array}$ & $\begin{array}{l}\text { Dummy } \\
\text { Variable }\end{array}$ \\
\hline
\end{tabular}

Sumber: Ringkasan Peneliti, 2020

Teknik pengumpulan data yang digunakan dalam penelitian ini adalah dengan menggunakan kuesioner. Pengumpulan data dengan kuesioner dilakukan dengan cara memberikan sejumlah pertanyaan tertulis kepada responden sesuai dengan kondisi yang sebenarnya. Pengujian hipotesis dalam penelitian ini menggunakan analisis logistik biner. 


\section{Hasil dan Pembahasan}

Uji overall Model Fit atau uji keseluruhan model dilakukan untuk menguji variabel independen di dalam regresi logistik secara simultan mempengaruhi variabel dependen. Hasil output SPSS menunjukkan bahwa nilai $-2 \log$ likelihood yang memasukkan konstanta saja sebesar 54.548. Sedangkan nilai -2 log likelihood yang memasukkan konstanta dan variabel bebas adalah sebesar 38.471. Perbandingan kedua nilai -2 log likelihood tersebut sebesar 16.077. Perbandingan tersebut mengikuti sebaran chi square sebesar 16.077 dengan df 5. Berdasarkan hasil pengujian diperoleh nilai Sig. Model sebesar 0.007 karena nilai signifikansi lebih kecil dari 5\% maka dapat disimpulkan bahwa tingkat pendidikan, jenis usaha produkif, lama usaha, jumah zakat produktif, dan pendampingan secara simultan berpengaruh terhadap peningkatan pendapatan mustahik.

Pada uji Wald, pengujian hipotesis dilakukan secara parsial. Hasil uji wald menunjukkan bahwa variabel jenis usaha dan jumlah zakat produktif secara parsial berpengaruh positif signifikan terhadap peningkatan pendapatan mustahik. Sedangkan variabel tingkat pendidikan, lama usaha, dan pendampingan secara parsial tidak berpengaruh signifikan terhadap peningkatan pendapatan mustahik.

Besarnya nilai koefisien determinasi pada model regresi logistic ditunjukkan oleh nilai Nagelkerke $R^{2}$. Nilai Nagelkerke $R^{2}$ adalah sebesar 0.445 yang berarti variabelitas variabel dependen yang dapat dijelaskan oleh variabel independent adalah sebesar $44.5 \%$, sedangkan sisanya sebesar $55.5 \%$ dijelaskan oleh variabel-variabel lain diluar model penelitian.

Upaya untuk melihat apakah data empiris sesuai dengan model sehingga model dapat dikatakan fit, kecocokan atau kelayakan model regresi secara keseluruhan dalam hal ini digunakan uji Hosmer and Lemeshow's test. Nilai Chi-square sebesar 5.352 dengan signifikansi (p) sebesar 0.72. Berdasarkan hasil tersebut, karena nilai signifikansi lebih besar dari 0.05 maka model dapat disimpulkan mampu memprediksi nilai observasinya atau dapat disimpulkan mampu memprediksi nilai observasinya atau dapat dikatakan model dapat diterima karena cocok dengan data observasinya. Hasil uji multikolinieritas menunjukkan bahwa semua variabel independent mempunyai nilai tolerance lebih dari 0.10 dan nilai VIF $\leq 10$, sehingga dapat dikatakan bahwa ketika variabel peningkatan pendapatan sebagai variabel dependen tidak terjadi multikolinieritas pada model regresi.

Kekuatan prediksi dari model regresi untuk memprediksi kemungkinan mustahik mengalami peningkatan pendapatan adalah sebesar $69.6 \%$. Hal ini menunjukkan bahwa dengan model regresi yang digunakan, terdapat sebanyak 16 mustahik (69.6\%) dari total 23 mustahik yang mengalami peningkatan pendapatan. Kekuatan prediksi mustahik yang tidak mengalami peningkatan pendapatan sebesar $76.5 \%$, yang berarti bahwa dengan model regresi yang digunakan ada sebanyak 13 mustahik yang diprediksi tidak meningkat pendapatannya dari total 17 mustahik yang tidak mengalami peningkatan pendapatan. Dapat disimpulkan bahwa kekuatan prediksi atau ketepatan model dalam mengklasifikasikan observasinya adalah 72.55. 
Tabel 3

Hasil Uji Koefisien Regresi Logistik

\begin{tabular}{|c|c|c|c|c|c|c|c|}
\hline \multicolumn{8}{|c|}{ Variables in the Equation } \\
\hline & & $\mathrm{B}$ & S.E. & Wald & $\mathrm{df}$ & Sig. & $\operatorname{Exp}(B)$ \\
\hline \multirow{6}{*}{ Step $1^{\text {a }}$} & $\mathrm{X} 1$ & -.235 & .565 & .173 & 1 & .678 & .791 \\
\hline & $\mathrm{X} 2$ & 1.610 & .883 & 3.325 & 1 & .068 & 5.002 \\
\hline & $\mathrm{X} 3$ & .033 & .072 & .206 & 1 & .650 & 1.033 \\
\hline & $\mathrm{Ln} \_\mathrm{X} 4$ & 1.977 & 955 & 4.283 & 1 & .039 & 7.218 \\
\hline & $\mathrm{X} 5$ & 1.216 & .908 & 1.794 & 1 & .180 & 3.374 \\
\hline & Constant & -28.814 & 13.367 & 4.646 & 1 & .031 & .000 \\
\hline
\end{tabular}

a. Variable(s) entered on step 1: X1, X2, X3, Ln_X4, X5.

Berdasarkan hasil uji regresi logistik dari tabel 3 maka persamaan regresi yang didapat ditunjukkan pada persamaan 1 :

$\mathrm{Y}=-\mathbf{2 8 . 8 1}-0.24 \mathrm{X} 1+1.61 \mathrm{X} 2+0.03 \mathrm{X3}+1.98 \mathrm{LnX} 4+1.22 \mathrm{X} 5+\mathrm{e}$

Hasil uji hipotesis ditunjukkan pada tabel 4 mengenai ringkasan hasil penelitian.

Tabel 4

Ringkasan Hasil Uji Hipotesis

\begin{tabular}{llrrr}
\hline \multicolumn{1}{c}{ Hipotesis } & $\boldsymbol{\beta}$ & Sig & Hasil \\
\hline $\mathrm{H}_{1}$ & $\begin{array}{l}\text { Tingkat pendidikan berpengaruh positif terhadap } \\
\text { peningkatan pendapatan mustahik }\end{array}$ & -0.235 & 0.678 & Ditolak \\
$\mathrm{H}_{2}$ & $\begin{array}{l}\text { Jenis usaha berpengaruh positif terhadap } \\
\text { peningkatan pendapatan mustahik }\end{array}$ & 1.610 & 0.068 & Diterima \\
$\mathrm{H}_{3}$ & $\begin{array}{l}\text { Lama usaha berpengaruh positif trhadap } \\
\text { peningkatan pendapatan mustahik }\end{array}$ & 0.033 & 0.650 & Ditolak \\
$\mathrm{H}_{4}$ & $\begin{array}{l}\text { Jumlah zakat produktif berpengaruh positif } \\
\text { terhadap peningkatan pendapatan mustahik }\end{array}$ & 0.977 & 039 & Diterima \\
$\mathrm{H}_{5}$ & $\begin{array}{l}\text { Pendampingan berpengaruh positif terhadap } \\
\text { peningkatan pendapatan mustahik }\end{array}$ & 0.1 .216 & Ditolak \\
\hline
\end{tabular}

Sumber: Output SPSS, diolah 2020

\section{A. Pengaruh tingkat pendidikan terhadap peningkatan pendapatan mustahik}

Berdasarkan tabel uji pengaruh variabel secara parsial tingkat pendidikan tidak berpengaruh secara signifikan terhadap peningkatan pendapatan mustahik. Hasil penelitian ini menunjukkan bahwa tidak ada pengaruh tingkat pendidikan mustahik terhadap peningkatan pendapatan secara langsung yang artinya semakin tinggi jenjang pendidikan ditempuh oleh mustahik belum tentu pendapatannya meningkat.

Penelitian ini tidak sejalan dengan teori kualitas sumber daya manusia yang menekankan pentingnya jenjang pendidikan yang tinggi untuk meningkatkan kemampuan intelektual sehingga berdampak pada keberhasilan usaha. Namun, sesuai dengan teori kualitas sumber daya manusia yang menilai bahwa kualitas 
SDM dinilai bukan hanya dari kemampuan intelektual akan tetapi dilihat dari kemampuan emosional. Menurut Goleman kemampuan intelektual hanya menyumbang sekitar 20\% kesuksesan dan sisanya $80 \%$ dipengaruhi oleh kekuatan lain salah satunya kecerdasan emosional (Bayu \& Sukartha, 2019). Kecerdasan emosional merupakan kemampuan untuk mengelola dan mengenali emosi diri dan orang lain. Kecerdasan emosional mencakup pengendalian diri, semangat, ketekunan, serta kemampuan untuk memotivasi diri sendiri. Peningkatan pendapatan mustahik tidak dipengaruhi oleh tingginya tingkat pendidikan mustahik akan tetapi dipengaruhi oleh kualitas sumber daya manusia yang lain seperti kemampuan emosioal mustahik.

Hasil penelitian berbeda dilakukan oleh Ayuniyyah, et al (2018) dan Syafiq \& Suprayogi (2020) bahwa tingkat pendidikan memiliki pengaruh positif terhadap pendapatan. Hasil penelitian ini mendukung penelitian yang dilakukan Muhammad, et al (2018) dan Amir (2019) menyatakan bahwa tingkat pendidikan memang tidak berpengaruh positif terhadap pendapatan mustahik. Hal tersebut disebabkan karena pada umumnya mustahik memandang Pendidikan merupakan hal yang penting bagi pelaku usaha, namun untuk dapat mengelola usaha tidak diperlukan tingkat pendidikan yang tinggi (Amir, 2019).

\section{B. Pengaruh usaha produktif terhadap Peningkatan Pendapatan Mustahik}

Jenis usaha merupakan hal yang sangat penting dalam suatu usaha, karena terdapat asumsi yang mengatakan bahwa jenis usaha dengan prospek yang baik, memiliki peluang lebih besar untuk memperoleh hasil yang baik. Sebaliknya jenis usaha dengan prospek yang kurang baik akan berpengaruh terhadap hasil yang diperoleh. Berdasarkan tabel uji pengaruh variabel jenis usaha produktif memiliki nilai signifikansi sebesar $0.07<0,10$ yang menunjukkan bahwa jenis usaha produktif secara parsial berpengaruh signifikan terhadap peningkatan pendapatan mustahik.

Teori produksi pada dasarnya menjelaskan bagaimana dengan biaya minimum unit usaha dapat menghasilkan output tertentu atau memaksimumkan produksi. Proses produksi merupakan kegiatan menambah nilai guna suatu barang atau jasa (Ahyari, 2002). Kegiatan menambah nilai tersebut bermanfaat untuk meningkatkan kualitas produk yang dihasilkan sehingga diharapkan dapat menarik minat konsumen dan meningkatkan harga jual suatu produk. Selain itu, dengan dilakukan proses produksi maka pelaku usaha dapat meminimumkan biaya produksi yang digunakan. Dapat disimpulkan bahwa usaha yang melakukan proses produksi memiliki pengaruh yang lebih besar dalam meningkatkan pendapatan mustahik. Hal ini dikarenakan dalam proses produksi terdapat kegiatan menciptakan atau menambah nilai guna suatu produk atau jasa. Selain itu dengan melakukan proses produksi, pelaku usaha dapat meminimumkan biaya produksi yang digunakan sehingga keuntungan yang diperoleh lebih besar.

Hasil penelitian berbeda dilakukan oleh Muhammad, et al (2018) dan Amir (2019) bahwa jenis usaha tidak memiliki pengaruh yang signifikan terhadap 
pendapatan. Menurut Amir (2019) menyatakan bahwa jenis usaha tidak memiliki pengaruh positif terhadap pendapatan mustahik karena hal yang sangat penting dan utama yang berpengaruh terhadap omset usaha adalah nilai pinjaman. Mendukung hasil penelitian ini, Qomariah (2019) bahwa jenis usaha memiliki pengaruh positif terhadap peningkatan pendapatan.

\section{Pengaruh Lama Usaha terhadap Peningkatan Pendapatan Mustahik}

Berdasarkan hasil penelitian diperoleh bahwa lama usaha mempunyai pengaruh negatif terhadap peningkatan pendapatan mustahik. Hal ini sesuai dengan uji pengaruh variabel lama usaha yang menunjukkan nilai signifikansi sebesar 0.70 yang menunjukkan nilai tersebut $>0.05$ yang berarti bahwa secara parsial lama usaha tidak berpengaruh signifikan terhadap peningkatan pendapatan mustahik. Semakin lama usaha dijalankan maka pendapatan mustahik belum tentu mengalami kenaikan.

Hasil penelitian ini tidak relevan dengan teori yang menyebutkan bahwa lama usaha dapat mempengaruhi produktivitas, semakin lama usaha dijalankan maka akan semakin tinggi produktivitas yang mengarah pada efisiensi biaya (Asmie, 2008). Pengetahuan yang terbentuk dari pengalaman yang dilalui menjadi salah satu faktor yang membentuk kualitas sumber daya manusia. Antara \& Aswitari (2016) menyebutkan bahwa lama usaha dapat mempengaruhi tingkat pendapatan, semakin lama usaha yang dimiliki maka produktivitas juga akan meningkat. Berdasarkan teori kualitas sumber daya manusia, pengalaman yang akhirnya memberikan pengetahuan dapat mempengaruhi dalam proses pencapaian tujuan. Dalam penelitian ini didapatkan hasil yang berkebalikan karena pengalaman sebagai salah satu faktor yang memberikan pengetahuan dan pemahaman tambahan tidak memiliki pengaruh positif terhadap peningkatan pendapatan mustahik.

Hasil penelitian ini tidak sesuai dengan penelitian yang telah dilakukan oleh Muhammad, et al (2018), Amir (2019), Syafiq \& Suprayogi (2020) yang membuktikan bahwa lama usaha berpengaruh positif terhadap peningkatan pendapatan mustahik. Semakin lama pelaku usaha menekuni usahanya, maka akan semakin banyak pengalaman yang didapatkan oleh pelaku usaha, baik dari segi pengetahuan maupun keterampilan dalam menjalankan usaha, serta semakin lama usaha berdiri maka kondisi usaha tersebut akan relatif lebih stabil jika dibandingkan dengan usaha yang berdiri.

Lama usaha tidak berpengaruh terhadap peningkatan pendapatan usaha disebabkan karena kurangnya pemahaman dan penyesuaian pedagang terhadap kondisi pasar (Nabela, 2017). Setiap pelaku usaha seharusnya memahami setiap kondisi yang terjadi dan diharapkan bisa segera melakukan penyesuaian diri. Dwipayanti \& Kartika (2020) menyatakan bahwa lama usaha tidak berpengaruh terhadap pendapatan disebabkan karena unit usaha yang dijalankan masih baru dan kinerja usaha kurang optimal karena pengelolaan yang tidak sesuai. Selain itu, kurangnya motivasi untuk mengembangkan usaha bisa menjadi faktor yang sangat berpengaruh terhadap keberhasilan usaha mustahik. 


\section{Jumlah Zakat terhadap Peningkatan Pendapatan Mustahik}

Hasil penelitian yang telah dilakukan diperoleh hasil bahwa jumlah zakat mempunyai pengaruh positif dan signifikan terhadap peningkatan pendapatan mustahik. Hal ini terlihat dari hasil uji pengaruh variabel jumlah zakat produktif yang menunjukkan nilai signifikansi 0.04 yang berarti bahwa secara parsial jumlah zakat produktif berpengaruh signifikan terhadap peningkatan pendapatan mustahik. Hasil penelitian ini menunjukkan bahwa semakin besar jumlah zakat yang diberikan maka semakin besar juga pendapatan yang diterima oleh mustahik. Sebaliknya semakin sedikit bantuan zakat yang diberikan maka semakin kecil pendapatan yang diterima oleh mustahik.

Teori pemberdayaan menekankan bahwa orang memperoleh keterampilan, pengetahuan dan kekuasaan yang cukup untuk mempengaruhi kehidupannya dan kehidupan orang lain yang menjadi perhatiannya. Pemberdayaan juga dimaknai menyiapkan kepada masyarakat berupa sumber daya, kesempatan, pengetahuan dan keahlian sehingga dapat meningkatkan kapasitas diri masyarakat dalam menentukan masa depannya sehingga dapat berpartisipasi dan mempengaruhi kehidupan dalam komunitas masyarakat tersebut. Bentuk pemberdayaan ini salah satunya dengan memberikan bantuan modal dalam hal ini berupa bantuan zakat produktif dengan harapan mustahik sebagai penerima modal mampu meningkatkan kualitas hidupnya. Jepkorir \& Mwangigichure (2019) menyampaikan bahwa "microcredit credit significantly improved growth of SMEs".

Hasil penelitian ini sesuai dengan teori pemberdayaan bahwa modal sebagai salah satu bentuk pemberdayaan berpengaruh terhadap peningkatan pendapatan mustahik. Dengan meningkatkan jumlah modal yang digunakan maka akan meningkatkan pendapatan yang diperoleh sebab usaha yang akan dirintis akan luas dengan adanya modal yang besar. Bantuan zakat produktif yang diberikan dapat membantu mustahik sebagai pelaku usaha untuk mengembangkan usahanya. Hasil penelitian ini relevan dengan penelitian yang dilakukan oleh Nabela (2017), Setiaji \& Fatuniah (2018), Amir (2019), Syafiq \& Suprayogi (2020) yang menjelaskan bahwa besar kecilnya jumlah dana yang diberikan mempengaruhi pendapatan yang diterima, semakin besar modal maka akan semakin besar pula pendapatan yang diterima. Hal ini menunjukkan bahwa jumlah dana zakat yang disalurkan benarbenar mempengaruhi pendapatan mustahik, semakin tinggi dana yang disalurkan maka akan semakin tinggi pula pendapatan mustahik (Sartika, 2008).

\section{E. Pendampingan berpengaruh terhadap Peningkatan Pendapatan Mustahik}

Berdasarkan hasil penelitian yang telah dilakukan diperoleh hasil bahwa pendampingan tidak berpengaruh signifikan terhadap peningkatan pendapatan mustahik. Hal ini terlihat dari hasil uji pengaruh variabel pendampingan yang memiliki signifikansi > 0.05 yaitu 0.18 . Hasil penelitian menunjukkan bahwa keikutsertaan mustahik dalam kegiatan pendampingan memiliki pengaruh positif terhadap pendapatan mustahik. 
Wilson menyebutkan terdapat empat tahapan dalam proses pemberdayaan yaitu penyadaran, pemahaman, pemanfaatan, dan penggunaan yang dalam pelaksanan dan penyesuaiannya memerlukan pembinaan dan proses yang cukup lama. Pemberdayaan dilakukan dengan memberikan pelatihan, pengawasan dan pendampingan. Pendampingan merupakan kegiatan yang dilakukan dengan menempatkan tenaga pendamping sebagai fasilitator, komunikator, motivator dan dinamisator. Dengan memberikan pendampingan diharapkan mereka sadar dan paham akan kemampuan dan potensi diri serta lingkungan sehingga kondisi mereka lebih baik. Hasil penelitian ini tidak sesuai dengan teori pemberdayaan karena pendampingan sebagai sarana penyadaran dan pemahaman dalam penelitian ini tidak berpengaruh signifikan terhadap peningkatan pendapatan mustahik.

Penelitian serupa dilakukan oleh Amir (2019) menunjukkan bahwa pendampingan usaha memiliki pengaruh positif terhadap pendapatan mustahik. Pendampingan yang dilakukan oleh BAZNAS merupakan kegiatan yang dilakukan dengan tujuan agar apa yang dijalankan sesuai dengan tujuan awalnya, dalam artian pendampingan usaha dilakukan agar usaha yang telah dijalankan tetap berjalan dan berkembang. Kegiatan pendampingan bisa mendorong perkembangan usaha dan peningkatan pendapatan berjalan dengan optimal. Selain itu, adanya motivasi yang muncul dari diri mustahik mengakibatkan kegiatan pendampingan yang diberikan dapat berpengaruh secara maksimal.

Syafiq \& Suprayogi (2020) menyebutkan bahwa pendampingan usaha, pelatihan, dan pengawasan merupakan bentuk pemberdayaan. Sedangkan pemberdayaan harus dilakukan dalam bentuk pelatihan, pendampingan, dan pengawasan yang dilakukan secara berkala kepada masyarakat. Dengan demikian ketika BAZNAS memberikan zakat kepada mustahik harus dilakukan pendampingan secara maksimal agar dapat meningkatkan kesejahteraan sebagaimana yang diharapkan. Pendampingan yang dilakukan bertujuan agar mustahik memiliki kemampuan dan kepercayaan diri dalam menghadapi setiap permasalahan sehingga usaha yang dijalankan dapat berjalan dan berkembang.

\section{Kesimpulan}

Penelitian ini mengkaji pengaruh tingkat pendidikan, jenis usaha produktif, lama usaha, jumlah zakat produktif, dan pendampingan terhadap peningkatan pendapatan mustahik penerima manfaat zakat produktif pada BAZNAS Kabupaten Semarang. Analisis regresi logistik biner dilakukan untuk memenuhi tujuan studi ini. Hasil penelitian menunjukkan bahwa jenis usaha produktif dan jumlah zakat produktif berpengaruh signifikan terhadap peningkatan pendapatan mustahik. Hal tersebut menunjukkan bahwa untuk meningkatkan pendapatan mustahik lembaga zakat perlu mempertimbangkan jenis usaha yang dijalankan oleh mustahik dan jumlah bantuan yang diberikan. Semakin besar jumlah zakat produktif yang diberikan maka kemungkinan mengalami peningkatan pendapatan lebih besar. Dengan memberikan bantuan permodalan yang cukup dapat memperbesar peluang mustahik untuk meningkatkan pendapatan. Pada penelitian selanjutnya peneliti dapat menambahkan 
jumlah responden dan menggunakan indikator pengukuran yang berbeda dari penelitian ini.

\section{BIBLIOGRAFI}

Ahyari, A. (2002). Manajemen Produksi: Perencanaan Sistem Produksi (keempat). Yogyakarta: BPFE UGM. Google Scholar

Akhyadi, A. S., \& Sadikin, I. S. (2020). The Construct of Community Empowerment through Social Compass Strategy: Case Study of Empowerment in Processing Waste and Water Hyacinth. Educare: International Journal for Educational Studies, 13(1), 27-48. Google Scholar

Alomari, M., Almasarweh, M. S., \& Alwaqfi, A. (2020). Impact of Human Capital in Quality and Strategic Excellences Impact of Human Capital in Quality and Strategic Excellences. International Journal of Advanced and Technology, 29(7), 11702-11710. Google Scholar

Amir, M. F. (2019). Faktor Determinan Tingkat Pendapatan Mustahiq Penerima Zakat Produktif. Iqtishaduna: Jurnal Ekonomi Dan Keuangan Islam, 10(2), 151-160. Google Scholar

Antara, I. K. A., \& Aswitari, L. P. (2016). Beberapa Faktor yang Mempengaruhi Pendapatan Pedagang Kaki Lima di Kecamatan Denpasar Barat. E-Jurnal Ekonomi Pembangunan Universitas Udayana, 5(11), 1265-1291. Google Scholar

Anwas, O. (2013). Pemberdayaan Masyarakat di Era Global. Bandung: Alfabeta. Google Scholar

Asmie, P. (2008). Analisis Faktor-Faktor yang Mempengaruhi Tingkat Pendapatan Pedagang Pasar Tradisional di Kota Yogyakarta. Jurnal NeO-Bis, 2(2), 197-210. Google Scholar

Ayuniyyah, Q., Pramanik, A. H., Saad, N., \& Ariffin, M. I. (2018). Zakat for Poverty Alleviation And Income Inequality Reduction. Journal of Islamic Monetary Economics and Finance, 4(1), 85-100. Google Scholar

Bayu, N. L. L. W., \& Sukartha, I. M. (2019). Pengaruh Kecerdasan Intelektual , Kecerdasan Emosional, dan Kecerdasan Spiritual Pemilik pada Kinerja UMKM di Kabupaten Gianyar. E-Jurnal Akuntansi Universitas Udayana, 26(1), 2268-2292. https://doi.org/https://doi.org/10.24843/EJA.2019.v26.i03.p22 Google Scholar

BPS. (2010). Penduduk Menurut Wilayah dan Agama yang Dianut. Retrieved January 23, 2021, from https://sp2010.bps.go.id/index.php/site/tabel?tid=321\&wid=0 Google Scholar

BPS. (2020a). Gini Ratio Provinsi 2002-2020. Retrieved from 
https://bps.go.id/linkTableDinamis/view/id/1116 Google Scholar

BPS. (2020b). Persentase Penduduk Miskin Menurut Provinsi (Persen) 2019-2020. Retrieved from https://www.bps.go.id/indicator/23/192/1/persentase-pendudukmiskin-menurut-provinsi.html Google Scholar

Djohani, R. (2003). Partisipasi, Pemberdayaan, dan Demokrasi Komunitas. Bandung: Studio Driya Media. Google Scholar

Dwipayanti, N. K., \& Kartika, I. N. (2020). Pengaruh Modal, Pengalaman Kerja Dan Lama Usaha Terhadap Produktivitas Serta Pendapatan Bumdes Di Kabupaten Badung. E-Jurnal Ekonomi Pembangunan Universitas Udayana, [S.l.], 9(2),354 382. Google Scholar

Firdausi, S. N. M. (2019). Pengaruh Program Pemberdayaan Ekonomi terhadap Pendapatan Dhuafa ( Studi pada LAZNAS Yatim Mandiri Kabupaten Malang dan Kota Surabaya ). Jurnal Ilmiah Mahasiswa FEB Universitas Brawijaya, 7(2), 5760. Google Scholar

Foster, B., \& Seeker, K. R. (2001). Pembinaan untuk Meningkatkan Kinerja Karyawan. Jakarta: PT Toko Gunung Agung, Tbk. Google Scholar

Indonesia. (2003). Undang-Undang Republik Indonesia Nomor 20. Google Scholar

Jepkorir, I., \& Mwangigichure, J. (2019). Effects of Debt Financing on the Growth of Small and Medium Enterprises in Kapsabet Town , Nandi County. IOSR Journal of Business and Management (IOSR-JBM), 21(10), 1-13. https://doi.org/10.9790/487X-2110040113 Google Scholar

Khan, N. A. (2014). The Impact of Micro Finance on the Household Income and Consumption level in Danyore, Gilgit-Baltistan. International Journal of Academic Research in Economics and Management Sciences, 3(1), 1-9. https://doi.org/10.6007/IJAREMS/v3-i1/604 Google Scholar

Majid, A. R., \& Suparno. (2018). Pengaruh Modal dan Tenaga Kerja terhadap Pendapatan Home Industri Sepatu di Kabupaten Sidoarjo (Study Kasus di Kecamatan Krian). Jurnal Ekonomi Dan Bisnis, 3(1), 703-710. Google Scholar

Muda, I., \& Arfan, M. (2016). Pengaruh Jumlah Zakat Produktif, Umur Produktif Mustahik, Dan Lama Usahamustahik Terhadap Produktivitas Usahamustahik (Studi pada Baitul Mal Kota Banda Aceh). Jurnal Ilmiah Mahasiswa Ekonomi Akuntansi (JIMEKA), 1(1), 318-326. Google Scholar

Muhammad, H., Lubis, D., \& Hakim, D. B. (2018). Faktor-faktor yang Memengaruhi Keberhasilan Usaha Mustahik pada Program Zakat Produktif LAZ An-Nuur Factors Affecting The Success of Mustahik Enterprises in The Productive Zakat Program of LAZ An-Nuur. Jurnal Al-Muzara'ah, 6(1), 1-14. https://doi.org/10.29244/jam.6.1.1-14 Google Scholar 
Nabela, D. (2017). An Exploratory Study Of The Factors Affecting The Levels Of Incomes Among Traders In Tumenggungan Market, Kebumen Regency. Jurnal Pendidikan Dan Ekonimi, 6(1), 17-27. Google Scholar

Prawira D, I. . H., \& Dewi, H. U. (2019). The Analysis of Factors that Effect Business Development and Income of MSMEs in Denpasar City. International Research Journal of Management, IT \& Social Sciences, 6(4), 118-126. https://doi.org/https://doi.org/10.21744/irjmis.v6n4.664 Google Scholar

Puskas BAZNAS. (2019). Potensi Zakat di Indonesia. In BAZNAS (Ed.), Outlook Zakat Indonesia 2020 (pp. 1-20). Jakarta: www.puskasbaznas.com. Retrieved from https://www.puskasbaznas.com/publications/outlook/indonesia-zakat-outlook2020/1255-outlook-zakat-indonesia-2020 Google Scholar

Qomariah, H. N. (2019). Pengaruh Pendayagunaan Dana Zakat Produktif Terhadap Peninkatan Pendapatan Usaha Mikro (Studi Kasus Mustahik di Lembaga Amil Zakat El-Zawa UIN Maliki Malang). Jurnal Ilmiah Mahasiswa FEB Universitas Brawijaya, 7(2), 1-15. Google Scholar

Rahardjo, M. D. (2010). Intelektual, Intelegasi, dan Perilaku Politik dan Bangsa. Bandung: Mizan. Google Scholar

Sartika, M. (2008). Pengaruh Pendayagunaan Zakat Produktif terhadap Pemberdayaan Mustahiq pada LAZ Yayasan Solo Peduli Surakarta. La Riba Jurnal Ekonomi Islam, 2(1), 75-89. Google Scholar

Setiaji, K., \& Fatuniah, A. L. (2018). Pengaruh Modal , Lama Usaha dan Lokasi Terhadap Pendapatan Pedagang Pasar Pasca Relokasi. Jurnal Pendidikan Ekonomi Dan Bisnis, 6(1), 1-14. https://doi.org/10.21009/JPEB.006.1.1 Google Scholar

Soegoto, E. S. (2014). Entrepreneurship - Menjadi Pebisnis Ulung, Edisi Revisi. Jakarta: PT Elex MEdia Komputindo. Google Scholar

Suryanto, \& Muhyi, H. A. (2018). Profile and Problem of Micro, Small and Medium Enterprises in Bandung. Advances in Social Science, Education and Humanities Research (ASSEHR), 14(1), 48-52. https://doi.org/10.2991/icoposdev-17.2018.10 Google Scholar

Syafiq, abdul alaa, \& Suprayogi, N. (2020). Meta-Analysis: The Determination Of Factors That Influence Mustahik Revenue1 Analisis. Jurnal Ekonomi Syariah Teori Dan Terapan, 7(5), 826-835. https://doi.org/10.20473/vol7iss20205pp826835 Google Scholar

Taufiq, I. F., Kusnendi, \& Nurasyiah, A. (2018). The Effect of Productive Zakat , Business Experience, and Mentoring on Farmers ' Revenues ( Survey on Lumbung Desa Program by Sinergi Foundation in Cibaeud Village, Cigalontang District , Tasikmalaya Regency ). International Journal of Zakat, 3(3), 55-67. 
Retrieved from https://ijazbaznas.com/index.php/journal/article/view/95/48 Google Scholar

Vu, H. Van. (2020). The Impact of Education on Household Income in Rural Vietnam. $\begin{array}{lllll}\text { International Journal of Financial Studies, } & 8(1), & 11 .\end{array}$ https://doi.org/https://doi.org/10.3390/ijfs8010011 Google Scholar

\section{Copyright holder:}

Nur Khalim Darwiyati dan Asrori (2021)

First publication right:

Journal Syntax Literate

This article is licensed under:

(c) $\odot \ominus_{\mathrm{BY}}$ 